\title{
Gas Chromatography-Mass Spectrometry Analysis of Ulva fasciata (Green Seaweed) Extract and Evaluation of Its Cytoprotective and Antigenotoxic Effects
}

\author{
Idania Rodeiro, ${ }^{1}$ Sitlali Olguín, ${ }^{2}$ Rebeca Santes, ${ }^{2}$ José A. Herrera, ${ }^{3}$ \\ Carlos L. Pérez, ${ }^{4}$ Raisa Mangas, ${ }^{3}$ Yasnay Hernández, ${ }^{1}$ Gisselle Fernández, ${ }^{4}$ \\ Ivones Hernández, ${ }^{1}$ Sandra Hernández-Ojeda, ${ }^{2}$ Rafael Camacho-Carranza, ${ }^{2}$ \\ Ana Valencia-Olvera, ${ }^{2}$ and Jesús Javier Espinosa-Aguirre ${ }^{2}$ \\ ${ }^{1}$ Departamento de Farmacología, Centro de Bioproductos Marinos (CEBIMAR), Loma y 37, Vedado, Plaza de la Revolución, \\ 11300 La Habana, Cuba \\ ${ }^{2}$ Departamento de Medicina Genómica y Toxicología Ambiental, Instituto de Investigaciones Biomédicas, \\ Universidad Nacional Autónoma de México (UNAM), CP 70228, 04510 México, DF, Mexico \\ ${ }^{3}$ Universidad de la Habana, Zapata y G, Vedado, Plaza de la Revolución, 10400 La Habana, Cuba \\ ${ }^{4}$ Departmento de Bioquímica, Instituto de Ciencias Básicas y Preclínicas (ICBP) “Victoria de Girón”, Avenida 146, \\ Playa, 11300 La Habana, Cuba
}

Correspondence should be addressed to Jesús Javier Espinosa-Aguirre; jjea99@gmail.com

Received 25 June 2015; Revised 28 September 2015; Accepted 8 October 2015

Academic Editor: Dolores García Giménez

Copyright (C) 2015 Idania Rodeiro et al. This is an open access article distributed under the Creative Commons Attribution License, which permits unrestricted use, distribution, and reproduction in any medium, provided the original work is properly cited.

\begin{abstract}
The chemical composition and biological properties of Ulva fasciata aqueous-ethanolic extract were examined. Five components were identified in one fraction prepared from the extract by gas chromatography-mass spectrometry, and palmitic acid and its ethyl ester accounted for $76 \%$ of the total identified components. Furthermore, we assessed the extract's antioxidant properties by using the DPPH, ABTS, and lipid peroxidation assays and found that the extract had a moderate scavenging effect. In an experiment involving preexposition and coexposition of the extract $(1-500 \mu \mathrm{g} / \mathrm{mL})$ and benzo[a]pyrene (BP), the extract was found to be nontoxic to C9 cells in culture and to inhibit the cytotoxicity induced by BP. As BP is biotransformed by CYP1A and CYP2B subfamilies, we explored the possible interaction of the extract with these enzymes. The extract $(25-50 \mu \mathrm{g} / \mathrm{mL})$ inhibited CYP1A1 activity in rat liver microsomes. Analysis of the inhibition kinetics revealed a mixed-type inhibitory effect on CYP1A1 supersome. The effects of the extract on BP-induced DNA damage and hepatic CYP activity in mice were also investigated. Micronuclei induction by BP and liver CYP1A1/2 activities significantly decreased in animals treated with the extract. The results suggest that Ulva fasciata aqueous-ethanolic extract inhibits BP bioactivation and it may be a potential chemopreventive agent.
\end{abstract}

\section{Introduction}

Marine seaweeds have been harvested for several years in the Far East and Asia Pacific countries, where they are consumed as food. In the last decade, this practice has also extended to North America and Europe [1]. At present, the economic potential of the seaweed industry is widely recognized [2]. In addition, seaweeds are considered an attractive avenue for the screening of biologically active compounds, due to their biodiversity and safety $[2,3]$.
Until now, the seaweed species studied have shown variations in their chemical composition (proteins, carbohydrates, lipids, minerals, and vitamins) associated with the influence of environmental factors such as seasonal periods, temperature, light, salinity, location, and storage conditions [4]. Seaweeds are able to produce secondary metabolites with interesting bioactive properties, including antibacterial, antifungal, antiviral, and antioxidant effects [5-9]. Ulva fasciata Delile, also known as sea lettuce, grows abundantly along coastal seashores. The antioxidant and antibacterial 
properties of this seaweed have been previously reported $[10,11]$.

Many extracts or partially purified polysaccharides from various algae have shown antitumor activity against experimental tumors in animal models $[2,12,13]$. The mechanism underlying this effect could be related to their antioxidant properties or control of cell proliferation. Additionally, Ryu et al. [14] showed that the ethanolic extract of $U$. fasciata has anticancer activity associated with the modulation of apoptotic signals, including mitochondria- and caspasedependent processes, in human colon cancer HCT116 cells.

Cancer is a serious global health problem and the primary cause of morbidity and mortality in Cuba [15]. Thus, the search for novel nutraceuticals with potential benefits for the prevention or therapy of cancer is well justified. An aqueousethanolic extract of $U$. fasciata collected from the north coast of Cuba was obtained and analyzed. Phytochemical study of this extract shows a high content of chlorophyll b, carotenoids, protein, carbohydrates, fiber, $\mathrm{Ca}, \mathrm{Mg}, \mathrm{K}, \mathrm{Fe}, \mathrm{Zn}$, $\mathrm{Cr}$, and $\mathrm{Mn}[16]$.

In order to contribute to the chemical characterization of the $U$. fasciata extract, here we report some nonpolar constituents of the extract. A chloroform-diluted fraction of the extract was prepared and its composition was determined by using gas chromatography-mass spectrometry (GC-MS). We also studied the protective effects of the whole extract by assessing its ability to protect against benzo[a]pyrene(BP-) induced cytotoxicity in C9 hepatic cells in mice. The antioxidant capacity and inhibitory effects of $U$. fasciata on CYP1A1/2 and CYP2B1/2 activities involved in the metabolism of several human mutagens/carcinogens were also investigated.

\section{Materials and Methods}

2.1. Chemicals. Analytical-grade reagents and reference substances were obtained from Aldrich (Milwaukee, MN, USA). Phenobarbital (PB) was purchased from Abbott Laboratories (Mexico City, Mexico). Beta-naphthoflavone ( $\beta$-NF), resorufin, 7-ethoxyresorufin (ER), methoxyresorufin (MR), benzyloxiresorufin (BR), pentoxyresorufin (BR), NADPH, BP, 2,2-diphenyl-2-picrylhydrazyl (DPPH), 2,2'-Azino-bis(3ethylbenzothiazoline-6-sulfonic acid) $\left(\mathrm{ABTS}^{\circ+}\right)$, thiobarbituric acid (TBA), corn oil, and Giemsa stain were purchased from Sigma Chemicals Co. (St. Louis, MO, USA). Microsomes of Baculovirus expression systems from rat CYP1A1expressing insect cells (Supersomes) were purchased from BD-Gentest (Woburn, MA, USA).

2.2. Material. Ulva fasciata Delile (Chlorophyta) was collected from the estuary of Quibu River in Cuba $\left(82^{\circ} 27^{\prime} 48^{\prime \prime} \mathrm{W}\right.$ and $\left.23^{\circ} 53^{\prime} 04^{\prime \prime} \mathrm{N}\right)$. The seaweeds were collected by hand from the intertidal zone in October 2013. After collection, the materials were immediately washed to remove epiphytes and sand and transported to the laboratory. After washing with distilled water, the samples were dried at $60 \pm 1^{\circ} \mathrm{C}$ to constant weight, milled, and stored desiccated in plastic receptacles. Fifty grams of dried $U$. fasciata powder was continuously macerated with $500 \mathrm{~mL}$ of ethanol: $\mathrm{H}_{2} \mathrm{O}(1: 1 \mathrm{vol} / \mathrm{vol})$ for $24 \mathrm{~h}$ at room temperature. The extract obtained was filtered and concentrated to dryness under reduced pressure at $45^{\circ} \mathrm{C}$.

2.3. Gas Chromatographic/Mass Spectrometric Analysis. One hundred milligrams of the dried extract was partitioned within $\mathrm{CHCl}_{3} / \mathrm{H}_{2} \mathrm{O}(1: 1 \mathrm{v} / \mathrm{v})$. The resulting crude organic phase was filtered and concentrated to dryness under reduced pressure at $45^{\circ} \mathrm{C}$ by using a rotary vacuum evaporator. Then, the fraction obtained was analyzed by gas chromatographymass spectrometry (GC-MS).

The analyses were performed using a GC-MS system (Model QP 2010 series, Shimadzu, Tokyo, Japan) equipped with an autosampler model AOC-20i and an RTX-1 fused silica capillary column of $30 \mathrm{~m}$ in length, $0.25 \mathrm{~mm}$ in diameter, and $0.1 \mu \mathrm{m}$ of film thickness. The column oven temperature was programmed from 50 to $300^{\circ} \mathrm{C}$ for $2^{\circ} \mathrm{C} \mathrm{min}^{-1}$. Ionization of the sample components was performed in electron impact mode $(\mathrm{EI}, 70 \mathrm{eV})$. The temperature of the injector was fixed at $300^{\circ} \mathrm{C}$ and that of the detector at $310^{\circ} \mathrm{C}$. Helium (purity, 99.9995\%) was the carrier gas; its flow rate was fixed at $1 \mathrm{~mL} \mathrm{m^{-1 }}$. The mass range from 40 to $1000 \mathrm{~m} / z$ was scanned at a rate of $3.0 \mathrm{scans} / \mathrm{s}$. One microliter of the organic extract of $U$. fasciata was manually injected into the GC-MS system by using a Hamilton syringe, for total ion chromatographic analysis by split injection $(1: 40)$. The total running time of the GC-MS system was $15 \mathrm{~min}$. The relative percentage of each extract constituent was expressed as percentage with respect to peak area normalization. The conversion of analog data to digital data was performed using the GC Solution software.

\subsection{Antioxidant Study}

2.4.1. Assay of 2,2-Diphenyl-2-picrylhydrazyl (DPPH') Scavenging Activity. The antioxidant capacity of the extract was measured as DPPH radical scavenging ability according to the method described by Tabart [17] with minor modifications. DPPH $(1500 \mu \mathrm{L})$ in ethanol $(0.075 \mathrm{mg} / \mathrm{mL})$ was mixed with $750 \mu \mathrm{L}$ of the extract at five different concentrations (10-1500 $\mu \mathrm{g} / \mathrm{mL}$ ). A control sample (ethanol) and a reference sample (ethanol plus DPPH) were used. The antioxidant ascorbic acid was used as a positive control. The decrease in the absorbance (Abs) at $515 \mathrm{~nm}$ was determined using a UV-1201 spectrophotometer (Shimadzu, Japan), until the reaction plateau step was reached. The $\mathrm{IC}_{50}$ values were determined, where they represent the concentration of extract that caused $50 \%$ inhibition of the maximum effects, and the scavenging effect was calculated as a percentage of DPPH scavenged, where \% DPPH inhibition $=$ (control Abs sample Abs $) /($ control Abs $) \times 100$, control Abs $=$ ethanol + $\mathrm{DPPH}$ Abs and sample Abs = sample + DPPH Abs.

2.4.2. Assay of 2,2'-Azino-bis(3-ethylbenzothiazoline-6-sulfonic Acid) $\left(\mathrm{ABTS}^{\circ+}\right)$ Radical Scavenging Activity. The scavenging activity of $U$. fasciata extract was also tested as previously described [18]. Briefly, ABTS $^{\bullet+}$ solution $(7 \mathrm{mM})$ was mixed with potassium persulfate $(2.45 \mathrm{mM})$ and stored during $16 \mathrm{~h}$ in the dark to generate the $\mathrm{ABTS}^{\circ+}$ radical cations. Then, the ABTS $^{\circ+}$ absorbance was adjusted to $0.70 \pm 0.02$ at $734 \mathrm{~nm}$. Free radical scavenging activity of $U$. fasciata was assessed by 
mixing $300 \mu \mathrm{L}$ of test sample with $3.0 \mathrm{~mL}$ of $\mathrm{ABTS}^{\circ+}$ radical solution. The decrease in absorbance at $734 \mathrm{~nm}$ was measured after six minutes. The percentage inhibition was calculated as follows: Scavenging activity $(\%)=($ control Abs - sample Abs) $/($ control Abs $) \times 100$. The antioxidant capacity of $U$. fasciata was expressed as $\mathrm{IC}_{50}$ values $(\mu \mathrm{g} / \mathrm{mL})$.

2.4.3. Assessment of Lipid Peroxidation. The capacity of the inhibition of liver lipid peroxidation by $U$. fasciata extract was assessed as described elsewhere [19] with slight modifications. The livers of male mice were removed and placed on ice. One gram of tissue was homogenized in cold $0.1 \mathrm{M}$ Tris buffer at pH $7.4(1: 10 \mathrm{w} / \mathrm{v})$ in a tissue homogenizer (Sakura, Japan). The homogenates were centrifuged at $12000 \mathrm{rpm}$ for $5 \mathrm{~min}$ at $4^{\circ} \mathrm{C}$. Then, the extract was incubated at $37^{\circ} \mathrm{C}$ for $1 \mathrm{~h}$ with $1 \mathrm{~mL}$ of the homogenate solution. Afterward, $8.1 \%$ sodium dodecyl sulfate (SDS), $1.33 \mathrm{M}$ acetic acid ( $\mathrm{pH}$ 3.4 ), and $0.6 \%$ thiobarbituric acid (TBA) were added to the medium. The reaction mixture was incubated at $97^{\circ} \mathrm{C}$ for $1 \mathrm{~h}$ and later the absorbance was measured at $532 \mathrm{~nm}$. TBARS concentrations were estimated from a standard curve of malondialdehyde bis-(dimethyl acetal) and reported as nmol MDA/mg protein. Data was expressed as percentage of inhibition. It was calculated from the absorbance values of the control and experimental tubes and $\mathrm{IC}_{50}$ value was calculated. Experiment was repeated three times and values were represented as mean \pm S.E. of the experiments. Protein concentration was also determined [20].

2.5. Effects of U. fasciata Extract on BP-Induced Cytotoxicity in Hepatic C9 Cells. Rat hepatocytes clone 9 culture (gift from Dr. M. Marina-Silva, IFC, UNAM, Mexico) was grown in DMEM supplemented with $10 \%$ newborn calf serum, $50 \mathrm{U}$ penicillin $/ \mathrm{mL}$, and $50 \mu \mathrm{g}$ streptomycin $/ \mathrm{mL}$. For subcultures, 5 $\times 10^{5}$ cells at $1: 10$ dilution were plated in a $100 \mathrm{~mm}$ petri dish. The medium was changed every three days and the cells were harvested at $\sim 100 \%$ confluence with $0.25 \%$ trypsin-EDTA. For treatments, C9 cells were seeded at a density of 5,000 cells/well and allowed to grow and equilibrate for $24 \mathrm{~h}$.

To explore the potential toxicity of $U$. fasciata, the cells were exposed to a range of extract concentrations (10$1000 \mu \mathrm{g} / \mathrm{mL}$ ) for 24,48 , and $72 \mathrm{~h}$. For experiments conducted to evaluate cytoprotection, the concentrations of the extract tested were $1,5,10,100$, and $500 \mu \mathrm{g} / \mathrm{mL}$ at a BP concentration of $10 \mu \mathrm{M}$.

In the first experimental series, the cells were pretreated with increasing concentrations of the extract for $12 \mathrm{~h}$. Then, they were treated with the extract and $\mathrm{BP}$ for an additional period of $6 \mathrm{~h}$. In the second experimental series, the cells were treated with the extract for $12 \mathrm{~h}$; they were then washed and exposed to BP or to the extract plus BP for an additional $24 \mathrm{~h}$ or $48 \mathrm{~h}$ period. A third experimental series was performed in which the cells were exposed to both the extract and BP for 24 or $48 \mathrm{~h}$. Finally, cell viability was evaluated by conducting the [3-4, 5-dimethylthiazol-2-yl]-2,5-diphenyl tetrazolium bromide (MTT) assay as previously described [21]. The percentage of cell viability was calculated relative to that of the nontreated cells, which were assumed to be $100 \%$ viable.

\subsection{Effects on CYP1A and CYP2B Isoforms in Rat Liver Microsomes}

2.6.1. Preparation of Liver Microsomes. For the in vitro assays, liver microsomes were obtained from the phenobarbital and 5,6- $\beta$-naphthoflavone-induced $S_{9}$ fraction [22]. For the in vivo assay, microsomes were prepared from the liver of animals exposed to Ulva fasciata extract or controls. Livers were excised, washed, and homogenized in $0.15 \mathrm{M} \mathrm{KCl}$ solution. The homogenate was centrifuged for $10 \mathrm{~min}$ at $9000 \times \mathrm{g}$ and the supernatant was collected $\left(S_{9}\right.$ fraction). The $S_{9}$ fraction was further centrifuged at $100,000 \times \mathrm{g}$ for $60 \mathrm{~min}$ and the pellet was resuspended in $0.1 \mathrm{M}$ phosphate buffer $(\mathrm{pH} 7.4)$ and $0.25 \mathrm{M}$ sucrose and centrifuged again at the same conditions. The microsomal fraction was resuspended in $0.1 \mathrm{M}$ phosphate buffer (pH 7.4), $1 \mathrm{mM}$ EDTA, $0.1 \mathrm{mM}$ dithiothreitol (DTT), and $20 \% \mathrm{v} / \mathrm{v}$ glycerol. Protein concentration was determined [20] and the microsomal fraction was kept at $-80^{\circ} \mathrm{C}$ until use.

2.6.2. CYP1A and CYP2B Activities. The activities of CYP1Al-related ethoxyresorufin-O-deethylase (EROD), CYP1A2-related methoxyresorufin-O-demethylase (MROD), CYP2B1-related pentoxyresorufin-O-dealkylase (PROD), and CYP2B2-related benzyloxy-resorufin-O-dealkylase (BROD) were measured as described elsewhere [23] with minor modifications. The extract was added to the incubation mixtures as an aqueous solution. The incubation mixture containing different concentrations of the extract (or water as control), rat liver microsomes $(0.01-0.1 \mathrm{mg}$ ), substrate ( $1 \mu \mathrm{M} \mathrm{ER}, 5 \mu \mathrm{M} \mathrm{MR}, 5 \mathrm{nM} \mathrm{PR}$, or $20 \mathrm{nM} \mathrm{BR})$, and buffer with $\mathrm{pH} 7.6\left(50 \mathrm{mM}\right.$ Tris- $\left.\mathrm{HCl}, 25 \mathrm{mM} \mathrm{MgCl}_{2}\right)$ was incubated for $3 \mathrm{~min}$ at $37^{\circ} \mathrm{C}$. The reaction was started by the addition of NADPH $(0.5 \mathrm{mM})$ and was monitored for $3 \mathrm{~min}$, with the fluorescence signal being recorded every $15 \mathrm{~s}$. The activities were calculated from a standard curve of resorufin (5-50 $\mathrm{pmol} / \mathrm{mL})$.

\subsection{Biochemical Characterization of the Extract's CYPIA1} Inhibitory Effect. The final reaction mixture contained $1 \mathrm{pmol}$ CYP1A1 Supersome, $0.5 \mathrm{mM}$ NADPH, different ER concentrations, and $0,10,20,30,40$, and $50 \mu \mathrm{g} / \mathrm{mL}$ of $U$. fasciata extract. Appropriate controls without the tested extract were established. The reaction was started with the addition of NADPH. $V_{\max }$ and $K_{m}$ values were obtained from the $1 / y$ and $1 / x$-intercepts of a Lineweaver-Burk plot after incubation at $37^{\circ} \mathrm{C}$ for $10 \mathrm{~min}$. Furthermore, a kinetic analysis was performed by using the Dixon plot and replot of the Yintercept of the Linewaver-Burk plot.

\subsection{Antigenotoxic Effects of the Extract on the DNA Damage} Induced by BP. Male BALB/C mice $(18-20 \mathrm{~g})$ were obtained from Biomedical Research Institute, National University of Mexico (UNAM, Mexico, DF, México). The animals were adapted to standard conditions (temperature: $20 \pm 2^{\circ} \mathrm{C}$, humidity: 40-60\%, and $12 \mathrm{~h}$ light/dark cycle) for one week. They were fed with a commercial standard rat diet and water ad libitum. The experiment was conducted in accordance with the ethical guidelines for investigations with laboratory animals of the Institute of Biomedical Research, UNAM. 
The study was conducted using 4 experimental groups (5 animals per group). The animals were orally administered 10,100 , and $250 \mathrm{mg} / \mathrm{kg} U$. fasciata extract for 5 days. The control group received only distilled water (vehicle). One hour after administration of the last dose of the extract, the animals received $250 \mathrm{mg} / \mathrm{kg} \mathrm{BP}$ by the oral route. After $24 \mathrm{~h}$, the animals were sacrificed and their livers were removed, weighed, washed $(0.15 \mathrm{M} \mathrm{KCl})$, and conserved at $-70^{\circ} \mathrm{C}$ until the microsomal fraction was obtained.

2.8.1. Liver CYP1A1/1A2 Activities in Mouse Liver Microsomes. The formation of resorufin after $\mathrm{O}$-dealkylation of 7 ethoxyresorufin and 7-methoxyresorufin were measured in microsomes from treated and control animals is as described above.

2.8.2. Determination of Micronuclei (MN) Induction. Once the animals were sacrificed, both femurs were removed and freed from skin and muscle by traction. The proximal end of the femur was carefully shortened until the marrow canal became visible. One milliliter of serum was introduced into the bone canal and the femur was submerged in a centrifuge tube filled with fetal calf serum. The marrow was aspirated and flushed several times. Cells were centrifuged at $1000 \mathrm{rev} / \mathrm{min}$ for $5 \mathrm{~min}$. Two drops of the cell fraction were placed onto clean, dry slides and smeared, fixed in methanol, and stained with Giemsa 5\% (v/v) for $12 \mathrm{~min}$. The percentage of micronucleated cells was determined using a sample of 2000 polychromatic erythrocytes (PCE). Normochromatic erythrocytes (NCE) were also scored in 2000 erythrocyte samples to determine the PCE/NCE ratio [24].

2.9. Statistical Analysis. Results were expressed as the mean $\pm \mathrm{SD}$ from three independent experiments. The statistical analysis was performed by one-way ANOVA, followed by a Dunnett's test for multiple comparisons using the GraphPad Prism 5 statistical software package. Statistical significance $(p)$ was set at 0.05 .

\section{Results}

3.1. Chemical Characterization of $U$. fasciata Extract. The chromatogram obtained from the GC-MS analysis of the fraction obtained after elution with $\mathrm{CHCl}_{3} / \mathrm{H}_{2} \mathrm{O}(1: 1 \mathrm{v} / \mathrm{v})$ from the $U$. fasciata extract showed 8 chromatographic peaks from 6 to $10 \mathrm{~min}$ and 5 new components were identified (Figure 1, Table 1). Most of the compounds and their derivatives were acidic in nature. The main component was palmitic acid (51.3\%) and its ethyl ester (24.7\%). These results increase the knowledge on the phytochemical composition of $U$. fasciata extract and it should add to the understanding of the product pharmacological properties.

3.2. Antioxidant Capacity of $U$. fasciata Extract. As the antioxidant activity is usually system-dependent, three methods were used to test the antioxidant effectiveness of this product, including two based on the evaluation of the freeradical scavenging capacity of the extract in a cell-free system and one based on its effects on lipid peroxidation in liver
TABLE 1: Compounds isolated from Ulva fasciata extract.

\begin{tabular}{lcc}
\hline Compounds & RT $(\mathrm{min})$ & Area $(\%)$ \\
\hline Azelaic acid & 6.205 & 3.08 \\
NI & 6.886 & 2.79 \\
n-Pentadecanoic acid & 6.922 & 1.21 \\
Hexahydrofarnesyl acetone & 7.344 & 11.84 \\
Palmitic acid & 7.787 & 51.31 \\
Palmitic acid ethyl ester & 7.928 & 24.67 \\
\hline
\end{tabular}

RT: retention time \%; relative percentage of the each extract constituent expressed as percentage with respect to peak area normalization.

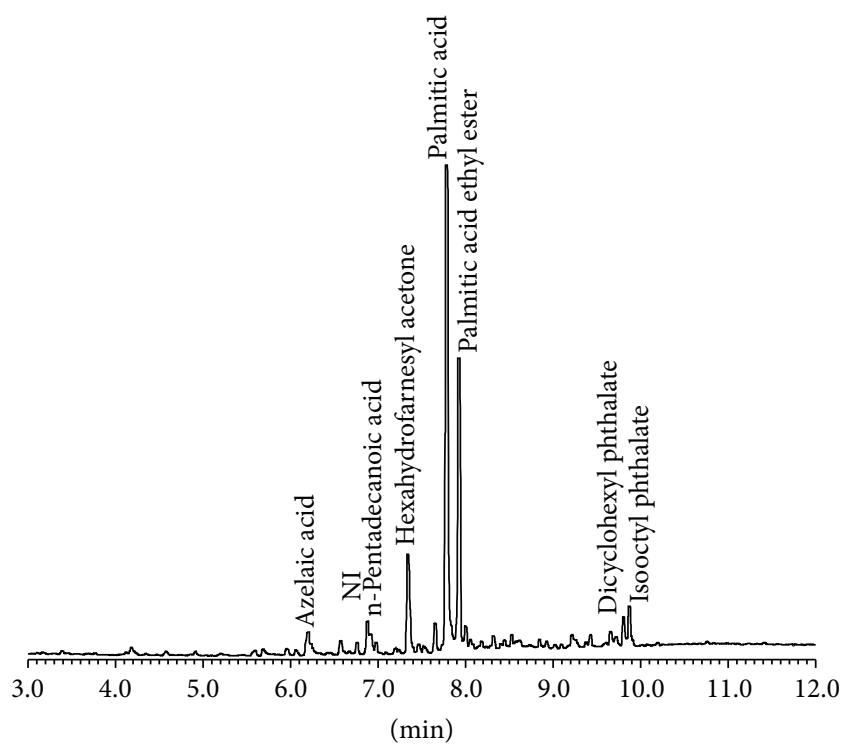

FIGURE 1: Chromatogram obtained by GC/MS analysis of the extract of Ulva fasciata.

homogenates. Results concerning the antioxidant capacity of the extract are shown in Figure 2. As it can be seen in cell-free systems, the extract showed a moderate scavenging effect, showing $\mathrm{IC}_{50}$ values of $155.3 \mu \mathrm{g} / \mathrm{mL}$ and a maximum effect of $58.26 \%$ at the concentration of $500 \mu \mathrm{g} / \mathrm{mL}$ in the $\mathrm{DPPH}$ assay. Meanwhile, for the $\mathrm{ABTS}^{\bullet+}$ radical the $\mathrm{IC}_{50}$ value was in the order of $240.4 \mu \mathrm{g} / \mathrm{mL}$ and the maximum effect was observed at $500 \mu \mathrm{g} / \mathrm{mL}$. In accordance with these results, $U$. fasciata inhibited lipid peroxidation when added to liver homogenates, showing $\mathrm{IC}_{50}$ values of $259.4 \mu \mathrm{g} / \mathrm{mL}$. In all the cases, the positive control (ascorbic acid) showed the expected effect (Figure 2).

3.3. Effects of U. fasciata Extract on the BP-Induced Cytotoxicity in Hepatic C9 Cells. In vitro toxicity effects of Ulva fasciata extract were evaluated in the C9 cell line. No significant cytotoxic effects were observed after exposing cells to Ulva fasciata for 24-72 h at any of the concentrations tested (10$1000 \mu \mathrm{g} / \mathrm{mL}$ ) (data not shown). In order to evaluate the potential cytoprotection of Ulva fasciata against the toxicity induced by the BP, the viability of $\mathrm{C} 9$ cells was scored after different treatment protocols. Exposure of C9 cells to BP induced the expected reduction in cell viability; however, 

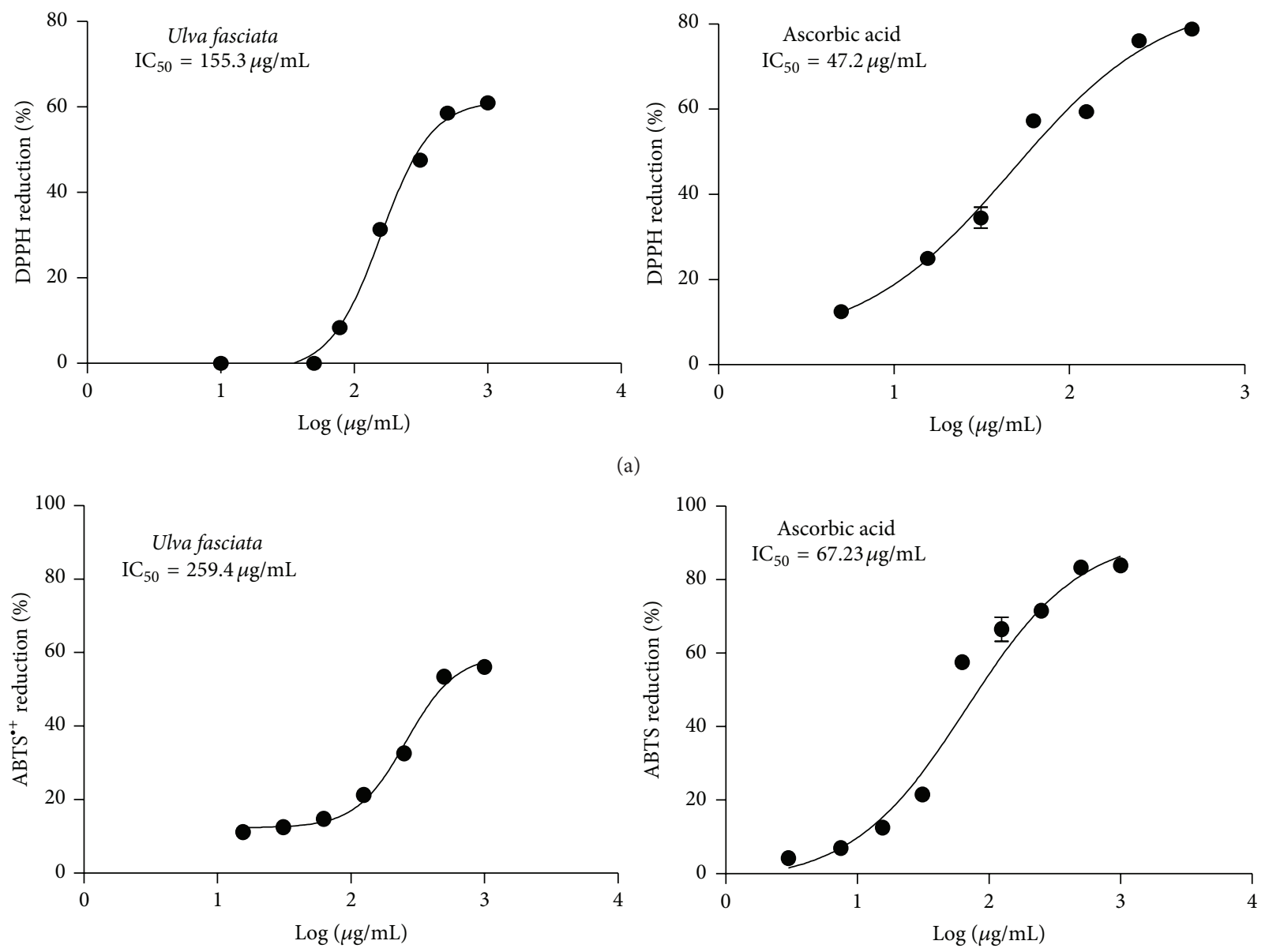

(b)
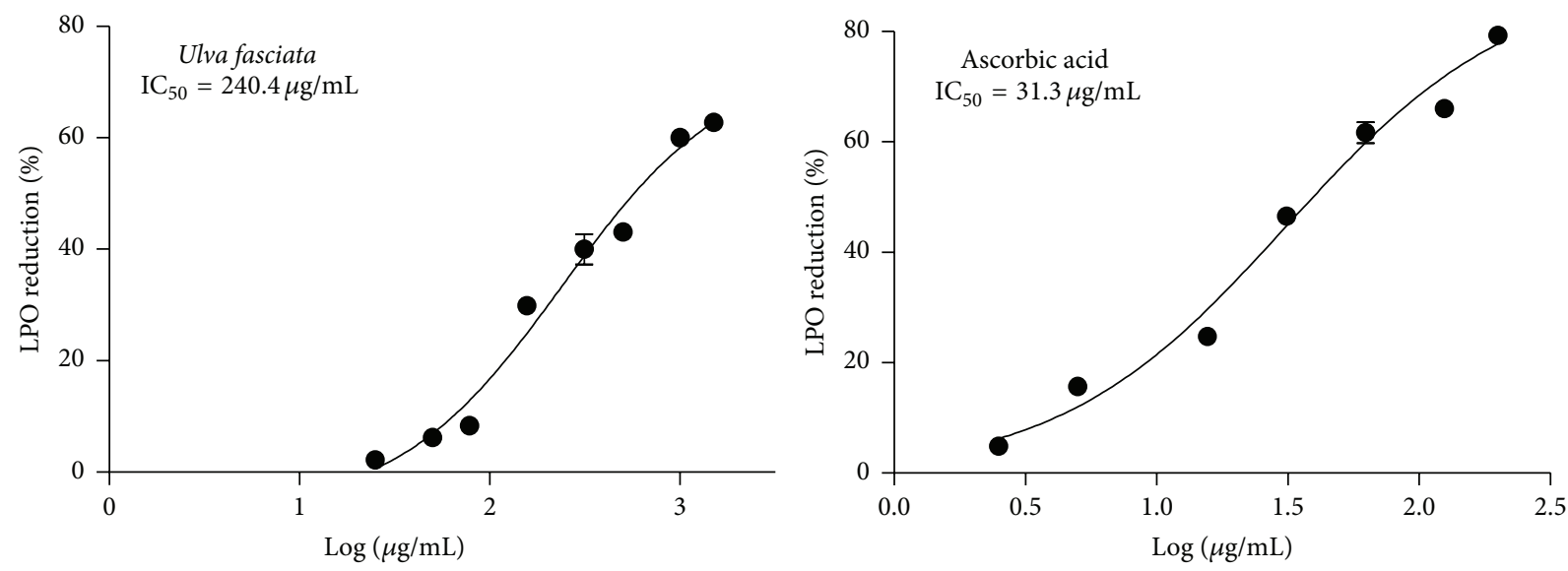

(c)

Figure 2: Antioxidant effects of Ulva fasciata extract. (a) DPPH radical, (b) ABTS ${ }^{\bullet+}$ radical, and (c) lipid peroxidation assay. Results represent the mean value $\pm \mathrm{SD}$ of three experiments carried out in triplicate. Antioxidant effectiveness was expressed as $\mathrm{IC}_{50}$. Ascorbic acid was used as standard. Coefficients of covariance were minor of 15 percent in all the cases.

a noticeable recovery was observed when the cells were preexposed to the extract (Figure 3). A similar level of recovery was noted in the cells coexposed to the extract plus BP, whereas the protective effect was more evident at the lower concentrations tested ( 1 and $5 \mu \mathrm{g} / \mathrm{mL}$ ), being significantly different than control cells. In addition, the exposure time where the effects of the extract were more consistent was $48 \mathrm{~h}$ (Figure 3).

3.4. In Vitro Effect of U. fasciata Extract on Hepatic P450 Activities. The activities of CYP1A1, CYP1A2, CYP2B1, and CYP2B2 were measured in induced rat liver microsomes 

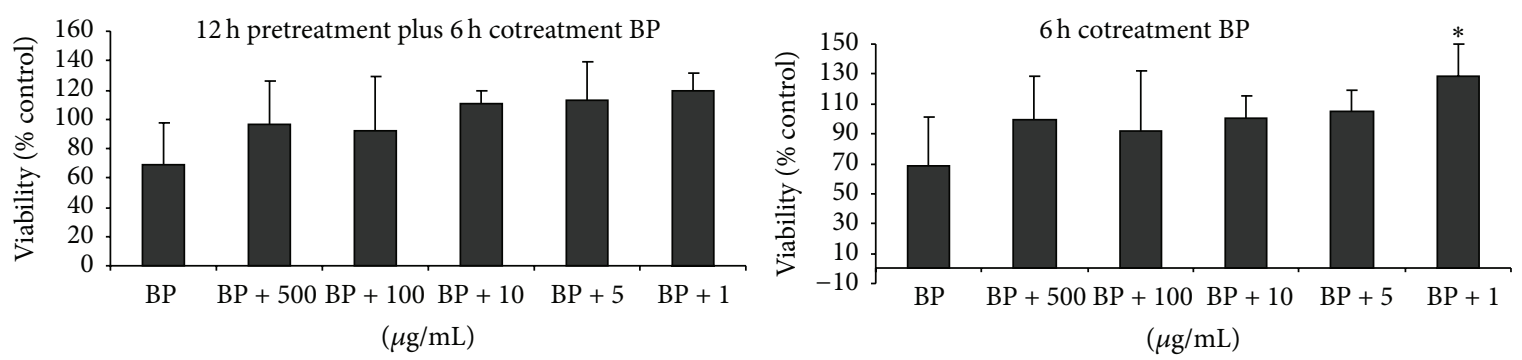

(a)
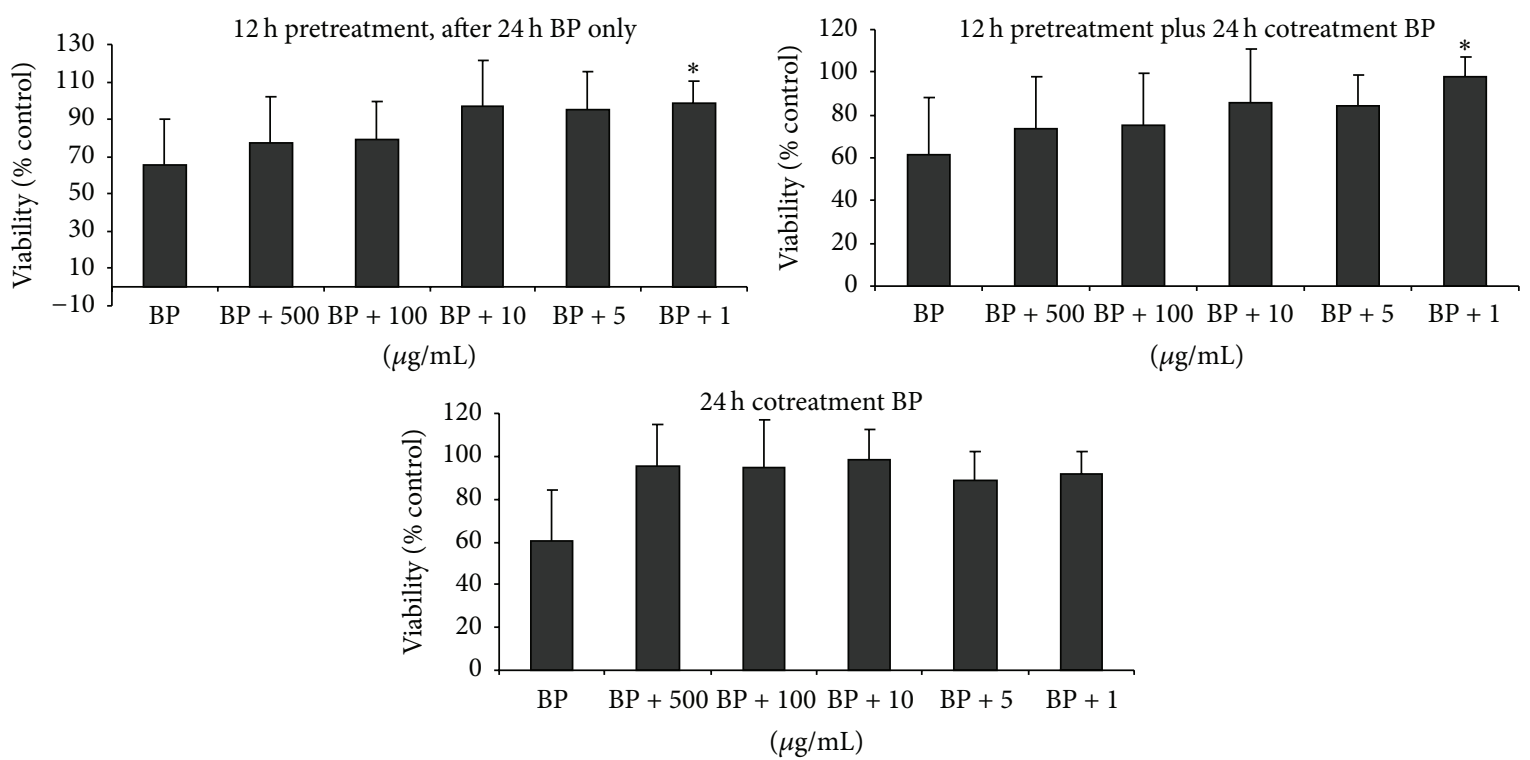

(b)
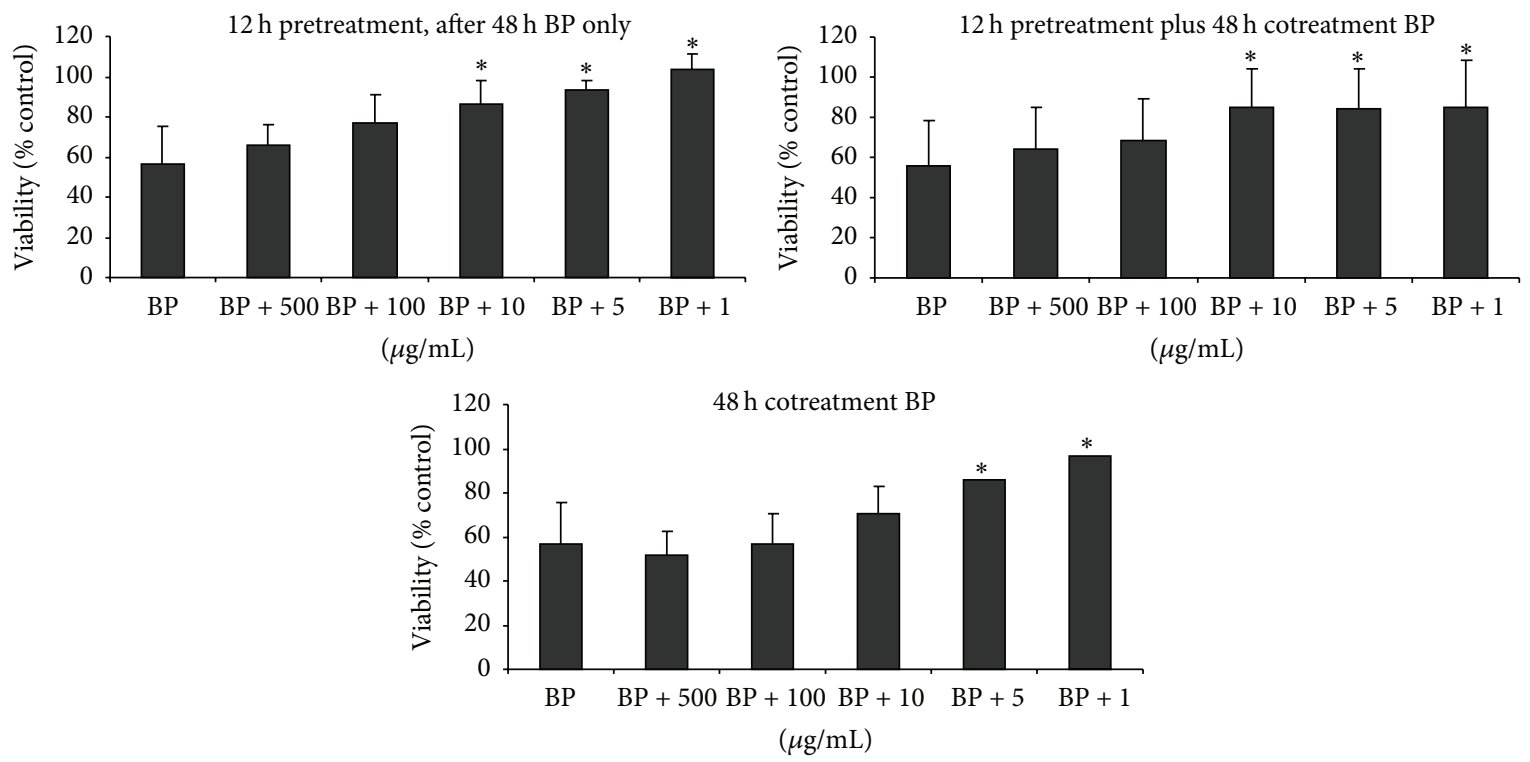

(c)

Figure 3: Effects of the Ulva fasciata extract on benzo[a]pyrene- (BP-) induced toxicity to rat C9 cells. (a) Cells were exposed for $12 \mathrm{~h}$ to increasing concentrations of Ulva fasciata extract and for an additional $6 \mathrm{~h}$ period in the presence of the extract and BP, or they were exposed for a $6 \mathrm{~h}$ period to both products. (b) Cells were exposed for $12 \mathrm{~h}$ to increasing concentrations of the extract; then, they were washed and exposed to the extract plus BP or BP only for an additional $24 \mathrm{~h}$ period. In the other condition, cells were exposed to both products for $24 \mathrm{~h}$. (c) Cells were treated in conditions similar to those described in (b); however, in this case, the additional period was $48 \mathrm{~h}$ long. In all series, the BP concentration used was $10 \mu \mathrm{M}$. Finally, cell viability was determined by the MTT assay. Results are expressed as the percentage of control (untreated) cells. Each point represents the mean \pm SD of three experiments with three replicates. ${ }^{*} p<0.05$ in relation to cells treated to the toxin (Dunnett's test). 

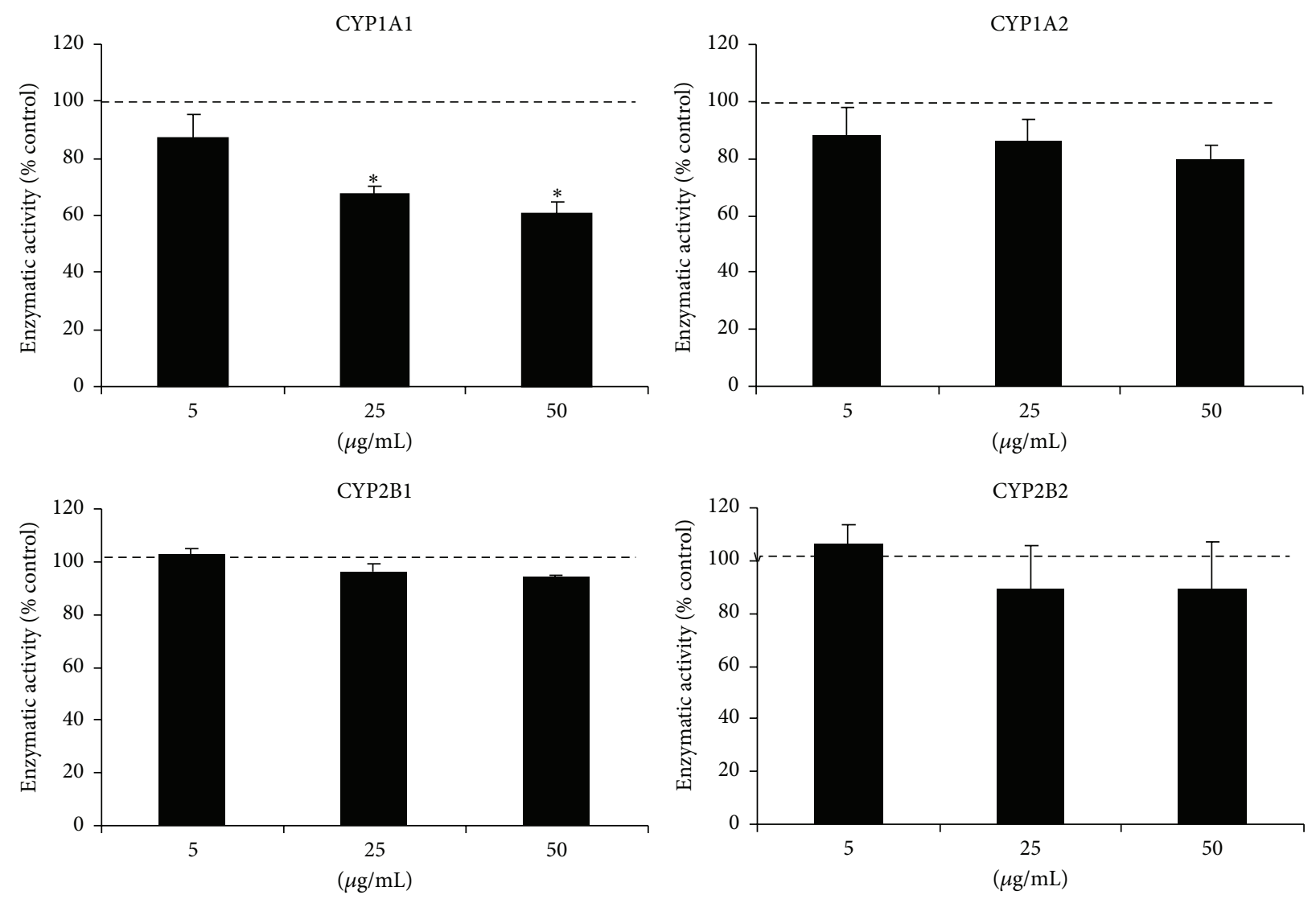

FIgURE 4: Effects of Ulva fasciata extract on microsomal P450 activities in rat PB-induced microsomes. P450 isoform activities were assayed in rat PB-induced microsomes incubated with appropriated substrates and Ulva fasciata concentrations. The values represent mean \pm SEM of three independent experiments, ${ }^{*} p<0.05$ (Dunnett's test).

alone, or in the presence of the extract at concentrations of 5 , 25 , and $50 \mu \mathrm{g} / \mathrm{mL}$. As seen in Figure 4, the extract produced a significant reduction of $35-40 \%$ in CYP1A1-associated EROD activity with respect to the activity recorded in the controls. A slight nonsignificant inhibition was observed for CYP1A2-associated MROD activity. No appreciable changes in CYP2B activity were found. Taking into account the above-mentioned results, we decided to investigate the type of inhibition produced by the extract on CYP1Al catalytic function. The kinetic parameters of rat recombinant CYP1A1 (Supersomes), using ethoxyresorufin as the substrate, were $V_{\max }=2677 \pm 51 \mathrm{pmol} / \mathrm{min} / \mathrm{mg}$ protein and $K_{m}=1.44 \pm$ $0.07 \mu \mathrm{M}$ (Table 2). CYP1A1 activity was inhibited in the presence of the extract at concentrations of $10-50 \mu \mathrm{g} / \mathrm{mL}$ (Figure 5), with a Ki of $67.9 \pm 9.3 \mu \mathrm{g} / \mathrm{mL}$ (Table 2). Results in Figure 6 show the mixed-type inhibitory mechanism of the U. fasciata extract.

3.5. Effects of U. fasciata Extract on BP-Induced Genotoxicity in Male BALB/C Mice. The results in Table 3 shows that pretreatment of animals with different doses of the $U$. fasciata extract prevented an increase in the frequency of micronucleated bone marrow polychromatic erythrocytes (MNPCEs) observed in bone marrow cells of BP-exposed animals. The reductions ranged from 47 to $65 \%$. Compared to the controls, the treated animals groups showed no significant
TABLE 2: Effect of Ulva fasciata extract on kinetics parameters of CYP1A1 Supersome.

\begin{tabular}{lc}
\hline Kinetic parameters & Ulva fasciata \\
\hline$V_{\max }(\mathrm{pmol} / \mathrm{min} / \mathrm{mg}$ protein $)$ & $2677 \pm 51$ \\
$K_{m}(\mu \mathrm{M})$ & $1.44 \pm 0.07$ \\
Type of inhibition & Mixed type \\
$\mathrm{Ki}$ & $67.9 \pm 9.3 \mu \mathrm{g} / \mathrm{mL}$ \\
$\alpha \mathrm{Ki}$ & $130.8 \pm 15.5 \mu \mathrm{g} / \mathrm{mL}$ \\
\hline
\end{tabular}

changes in the cytotoxicity index. Additionally, no significant differences in body weight and water consumption were observed between the groups (data not shown).

On the other hand, the effects of the $U$. fasciata extract on the enzymatic activity of CYP1A1 and CYP1A2 in liver microsomes from the treated animals and controls are shown in Figure 7. Mice orally exposed to the extract for 5 days before BP exposure showed a decrease in hepatic CYP1A1 activity compared to the activity recorded in the BP-positive control group.

\section{Discussion}

The use of chemoprotective agents in everyday life has been suggested to be effective in preventing the increase of cancer 

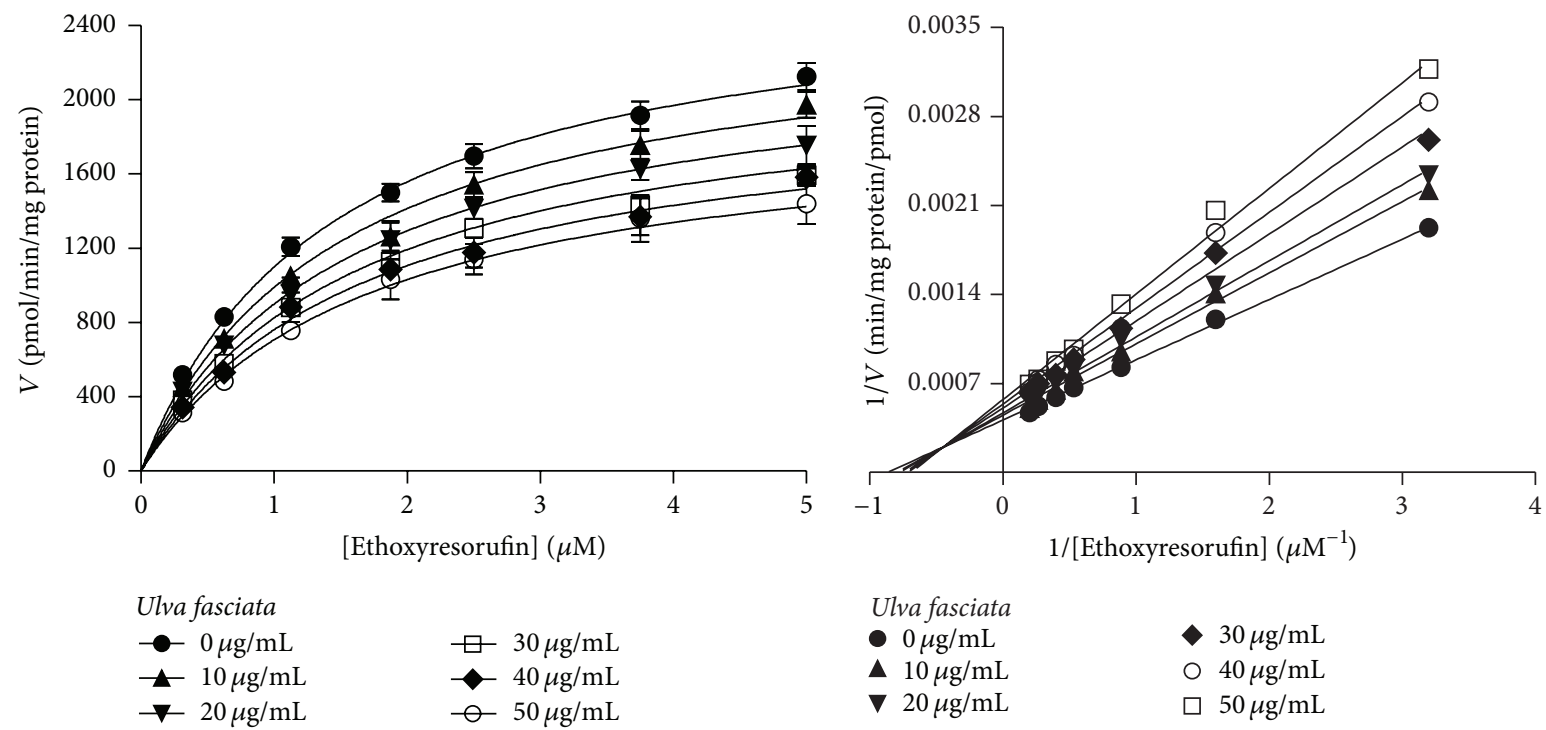

Ulva fasciata
- $0 \mu \mathrm{g} / \mathrm{mL}$
त $10 \mu \mathrm{g} / \mathrm{mL}$
V $20 \mu \mathrm{g} / \mathrm{mL}$

(a)

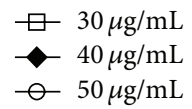

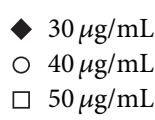

(b)

FIGURE 5: CYP1A1 associated ethoxyresorufin-O-deethylase activity in the absence and presence of different concentrations of Ulva fasciata. (a) Reaction in a final volume of $200 \mu \mathrm{L}$ was monitored for $10 \mathrm{~min}$ recording the fluorescence signal each $15 \mathrm{~s}$. The reactions consisted of 1 pmol Supersome protein, $50 \mathrm{mM} \mathrm{NADPH}$, and ethoxyresorufin at different concentrations. For the inhibition experiments, the extract was added at different concentrations to the reaction mixture. (b) Lineweaver-Burk plot analysis was performed to obtain the kinetic parameters. Each point in (a) represents the mean \pm SD obtained from three independent experiments.

TABLE 3: Effects of Ulva fasciata extract on micronucleus assay in $\mathrm{Balb} / \mathrm{C}$ male mice.

\begin{tabular}{lcc}
\hline Group (mg/kg) & IC & MN/PCE \\
\hline Negative control & $10.8 \pm 0.28$ & $4.3 \pm 0.8$ \\
Vehicle control & $2.1 \pm 0.47$ & $6.6 \pm 2.6$ \\
Benzo(a)pyrene only & $2.23 \pm 0.75$ & $15.3 \pm 2.6$ \\
Benzo(a)pyrene + Ulva $(50 \mathrm{mg} / \mathrm{kg})$ & $2.48 \pm 0.50$ & $7.9 \pm 1.9^{* *}$ \\
Benzo(a)pyrene + Ulva $(100 \mathrm{mg} / \mathrm{kg})$ & $1.88 \pm 0.25$ & $5.3 \pm 1.4^{* *}$ \\
Benzo(a)pyrene + Ulva $(250 \mathrm{mg} / \mathrm{kg})$ & $2.63 \pm 0.47$ & $5.15 \pm 0.65^{* *}$ \\
\hline
\end{tabular}

MN: micronucleus; PCE: polychromatic erythrocytes; 2000 cells/animal were examined; IC: cytotoxicity index: polychromatic erythrocytes/normochromatic erythrocytes; ${ }^{* *} p<0.01$; comparisons between treated groups with the extract plus $\mathrm{PB}$ and the control group treated with BP only (Dunnett's test).

frequency in human populations. For instance, many dietary antioxidants were shown to be potentially beneficial agents by reducing oxidative stress involved in the development of different chronic diseases, including cancer [25].

Natural products contain bioactive constituents that potentially block or reverse the carcinogenesis process at early stages. Therefore, modification in lifestyle habits, including diet, may lead to a reduction in the incidence of these diseases [25]. The central point of this strategy is that dietary constituents may inhibit carcinogenesis through different mechanisms. Blocking biotransformation of procarcinogens through inhibition of the CYP system is one of them. During phase I of xenobiotic metabolism, polar metabolites are formed which are substrates for phase II enzymes in order to render easily excreted products. Nevertheless, metabolites resulting from phase I may be highly electrophilic and carcinogenic, capable of interacting with DNA, and causing mutations $[26,27]$.

In the present study, we demonstrated the in vitro scavenging properties and protective effects of $U$. fasciata extract on BP-induced damage, a recognized human carcinogen. The extract itself was not cytotoxic to hepatic C9 cells but it showed a cytoprotective effect against BP-induced cytotoxicity (Figure 3). Surprisingly, lower concentrations of the extract $(1 \mu \mathrm{g} / \mathrm{mL})$ completely abolished the cytotoxic effect of BP. Since BP exposure should give rise to electrophilic metabolites and the extract showed moderate scavenging activity measured as DPPH, ABTS, and lipid peroxidation assays (Figure 2), the cytoprotection observed may be due to a decrease of the oxidative stress in C9 cells induced by $U$. faciata extract. On the other hand, the significant in vitro and in vivo inhibitory effects of the extract on CYP1A1 activity (Figures 3 and 7) may play an important role in the protection from BP-induced damage. The extract showed mixed-type inhibition kinetics with increasing $K_{m}$ and decreasing $V_{\max }$ as the extract concentration increased (Figures 5 and 6 , Table 2). These results suggest that the active compound(s) in the extract might bind to both the active site of the enzyme and an allosteric site. To our knowledge, this is the first report concerning the potential chemopreventive effects of this green seaweed on DNA-induced damage.

It is known that BP induces genetic lesions such as DNA single-strand breaks, DNA-protein cross-links, and chromosomal aberrations [28]. In an attempt to demonstrate the in vivo antigenotoxic potential of the extract, we explored its capacity to reduce the frequency of micronuclei induced by $\mathrm{BP}$. The levels of BP-induced micronuclei were found to 


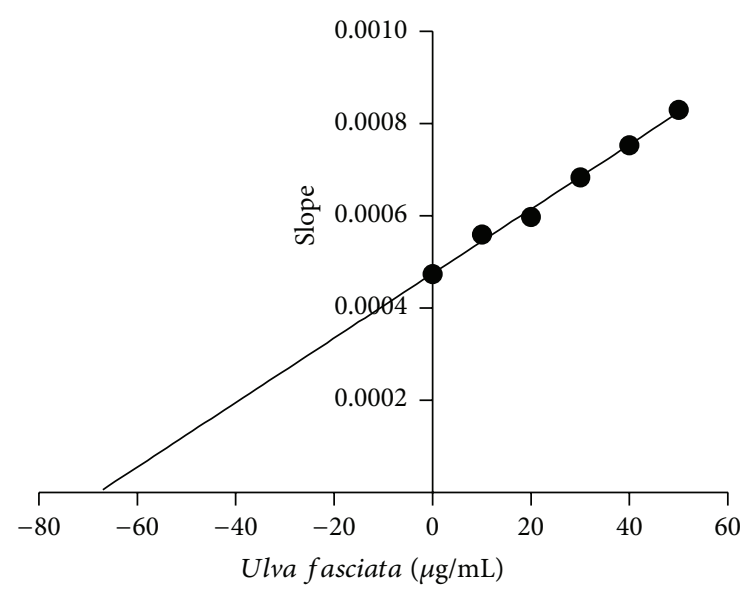

(a)

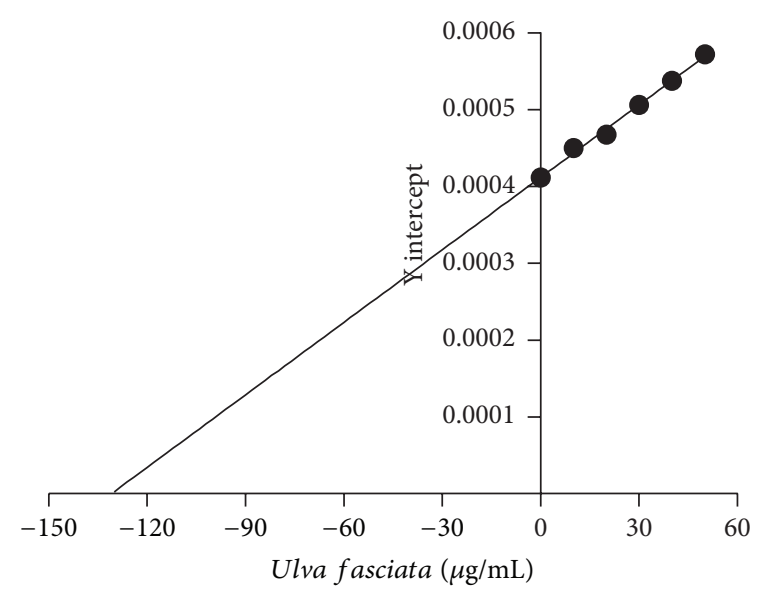

(b)

FIGURE 6: Confirmation of the CYP1A1 inhibitory properties of Ulva fasciata extract by (a) Dixon plot and (b) Y-intercept of the LinewaverBurk plot versus inhibitor's concentration. Each plot was obtained from independent reactions containing the desired concentration of ethoxyresorufin (0.31-5.00 $\mu \mathrm{M}), 1 \mathrm{pM}$ Supersome protein, $50 \mathrm{mM} \mathrm{NADPH}$, and different concentrations of the extract in a final volume of $200 \mu \mathrm{L}$. Each reaction was followed for $10 \mathrm{~min}$, with the fluorescence signal being recorded every $15 \mathrm{~s}$. Each point in (a) represents the mean \pm SD obtained from three independent experiments. Slope of each plot in (a) was obtained and plotted versus the inverse of the concentration of ethoxyresorufin (b).
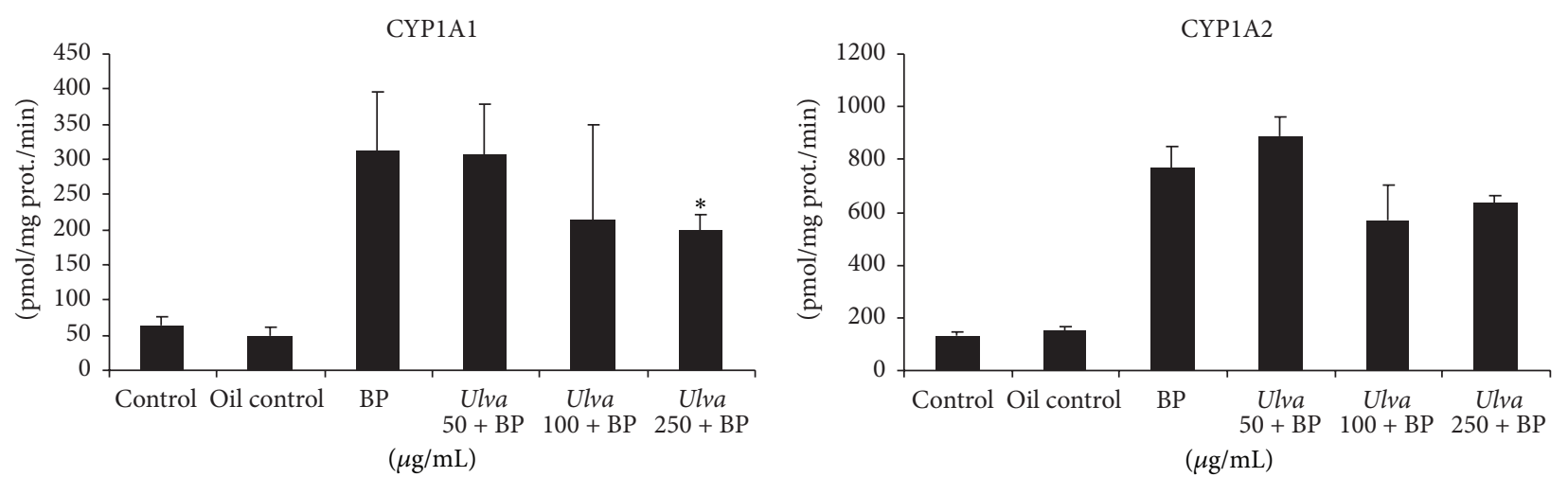

Figure 7: Effects of the pretreatment of Ulva fasciata extract on CYP1A activities in liver microsomes from male BALB/C mice exposed to benzo(a)pyrene (BP). CYP1A1 and CYP1A2 activities were assayed in liver microsomes from mice pretreated with different doses of Ulva fasciata or controls during 5 days and after administration of an oral dose of BP $(250 \mathrm{mg} / \mathrm{kg})$. The values represent mean $\pm \mathrm{SD} ;{ }^{*} p<0.05$ (Dunnett's test).

be significantly lower in the extract pretreated animals than in those exposed only to BP (Table 3 ), suggesting that $U$. fasciata protects against DNA damage resulted from endogenously reactive species produced during the intermediary metabolism of BP.

Interestingly, a dose-related decrease in hepatic CYP1A activity was detected in the three extract treated groups compared to the BP-treated group (Figure 7). This finding confirmed the results of the in vitro inhibition study described above (Figure 3), and it reinforces the hypothesis that inhibition of metabolizing enzymes may play an important role in $U$. fasciata antigenotoxic properties.

Thus, our results indicate that prevention of BP-induced genotoxic damage by the tested extract may involve the modulation of different molecular targets, where the interaction with Phase I enzymes associated with carcinogen activation (CYP1A subfamily) could play an important role. However, the radical scavenging properties of the extract and the modulation of other antitumor mediators at the cellular level could not be discarded. In addition, our present results as well as others [16] concerning the phytochemical characterization of this extract (Figure 1) indicated that $U$. fasciata is a rich source of many micro- and macronutrients, some of which are associated with the modulation of different biomarkers involved in cancer progression.

Fatty acids and carotenoid pigments are present at high concentrations in seaweeds, including the specie of $U$. fasciata studied here. Carbohydrates, proteins, saponins, alkaloids, and flavonoids are also found to be present $[29,30]$. Here, we broaden the phytochemical study of this extract by using GC-MS. The analysis performed in this study (Figure 1) showed palmitic acid to be one of the main components in the fraction analyzed, and the biological importance of this molecule has been highlighted [31]. Ryu et al. [14] reported 
the presence of carotenoids in the extract. Nadathur et al. [32] have reported the antimutagenic properties of palmitic acid against the direct mutagen methylnitronitrosoguanidine (MNNG). Its mechanism of action has been suggested to involve trapping of the mutagen inside the micelles formed by the fatty acid. Furthermore, the same group reported that isopalmitic acid also interferes with the mutagenicity of 7,12-dimethylbenz[a] anthracene (DMBA) by inhibiting the activity of CYP1A1. Whether or not the same mechanism of action could be considered for the antigenotoxic effect of $U$. fasciata extract reported here needs to be investigated further.

\section{Conclusion}

In summary, this study demonstrated that $U$. fasciata has protective effects against in vitro and in vivo damage induced by BP, and different pathways could be modulated by the extract. Meanwhile, its capacity for inhibiting CYP1A function seems to be the main mechanism involved. Thus, this marine green alga might be an abundant source of potential complementary and alternative functional food for the prevention of cancer and other degenerative diseases associated with xenobiotics bioactivation in the organism. The mechanisms underlying the antigenotoxic effects of $U$. fasciata deserve further investigation.

\section{Conflict of Interests}

The authors declare that there is no conflict of interests regarding the publication of this paper.

\section{Acknowledgments}

This work was supported by the UNESCO-TWAS Associateship Scheme at Centres of Excellence in the South program (grant to Dr. I. Rodeiro) and funds from UNAM, D.F., Mexico, and from the Research Project "Evaluación de las potencialidades químicas y farmacológicas de nuevos productos obtenidos de fuentes marinas con vistas a su aplicación como antimutagénos y anticancerígenos en el hombre" from Environmental Agency, Cuban Ministery of Science, Technology and Environmental (CITMA), Cuba. The authors would like to express their appreciation to Cynthia LimaCruz for critically reviewing the paper.

\section{References}

[1] D. J. H. McHugh, A Guide to the Seaweed Industry, Food and Agriculture Organization of the United Nations, Rome, Italy, 2003.

[2] A. B. A. Ahmed, M. Adel, P. Karimi, and M. Peidayesh, "Pharmaceutical, cosmeceutical, and traditional applications of marine carbohydrates," Advances in Food and Nutrition Research, vol. 73, pp. 197-220, 2014.

[3] S. Mohamed, S. N. Hashim, and H. A. Rahman, "Seaweeds: a sustainable functional food for complementary and alternative therapy," Trends in Food Science and Technology, vol. 23, no. 2, pp. 83-96, 2012.
[4] E. Marinho-Soriano, P. C. Fonseca, M. A. A. Carneiro, and W. S. C. Moreira, "Seasonal variation in the chemical composition of two tropical seaweeds," Bioresource Technology, vol. 97, no. 18, pp. 2402-2406, 2006.

[5] D. J. Faulkner, "Marine natural products," Natural Product Reports, vol. 19, no. 1, pp. 1-48, 2002.

[6] G. Schwartsmann, A. Brondani, R. G. S. Berlinck, and J. Jimeno, "Marine organisms and other novel natural sources of new cancer drugs," Annals of Oncology, vol. 11, no. 3, pp. 235-243, 2000.

[7] A. M. S. Mayer, A. D. Rodríguez, R. G. S. Berlinck, and M. T. Hamann, "Marine pharmacology in 2003-4: marine compounds with anthelmintic antibacterial, anticoagulant, antifungal, anti-inflammatory, antimalarial, antiplatelet, antiprotozoal, antituberculosis, and antiviral activities; affecting the cardiovascular, immune and nervous systems, and other miscellaneous mechanisms of action," Comparative Biochemistry and Physiology C: Toxicology and Pharmacology, vol. 145, no. 4, pp. 553-581, 2007.

[8] M. Plaza, S. Santoyo, L. Jaime et al., "Screening for bioactive compounds from algae," Journal of Pharmaceutical and Biomedical Analysis, vol. 51, no. 2, pp. 450-455, 2010.

[9] Z. Zhang, F. Wang, X. Wang, X. Liu, Y. Hou, and Q. Zhang, "Extraction of the polysaccharides from five algae and their potential antioxidant activity in vitro," Carbohydrate Polymers, vol. 82, no. 1, pp. 118-121, 2010.

[10] K. Chakraborty and R. Paulraj, "Sesquiterpenoids with freeradical-scavenging properties from marine macroalga Ulva fasciata Delile," Food Chemistry, vol. 122, no. 1, pp. 31-41, 2010.

[11] K. Chakraborty, A. P. Lipton, R. Paul Raj, and K. K. Vijayan, "Antibacterial labdane diterpenoids of Ulva fasciata Delile from southwestern coast of the Indian Peninsula," Food Chemistry, vol. 119, no. 4, pp. 1399-1408, 2010.

[12] G. F. Zhou, W. X. Sheng, W. X. Yao, and C. H. Wang, "Effect of low molecular lambda-carrageenan from Chondrus ocellatus on antitumor H-22 activity of 5-Fu," Pharmacological Research, vol. 53, no. 2, pp. 129-134, 2006.

[13] M. Schumacher, M. Kelkel, M. Dicato, and M. Diederich, "Gold from the sea: marine compounds as inhibitors of the hallmarks of cancer," Biotechnology Advances, vol. 29, no. 5, pp. 531-547, 2011.

[14] M. J. Ryu, A. D. Kim, K. A. Kang et al., "The green algae Ulva fasciataDelile extract induces apoptotic cell death in human colon cancer cells," In Vitro Cellular and Developmental Biology-Animal, vol. 49, no. 1, pp. 74-81, 2013.

[15] Anuario Estadístico de Salud, Reporte Anual acerca de los indicadores de salud en el país, Departamento Nacional de Estadística, Ministerio Salud Pública, MINSAP, Havana, Cuba, 2014.

[16] M. Cano, Bases biológicas de Ulva fasciata Delile, (Chlorophyta) para su posible explotación al oeste de la Habana, Cuba [Ph.D. thesis], School of Biology, Universidad de la Habana, Havana, Cuba, 2008.

[17] J. Tabart, "Comparative antioxidant capacities of phenolic compounds measured by various test," Food Chemistry, vol. 40, pp. 123-128, 2008.

[18] N. Nenadis, L. F. Wang, M. Tsimidou, and H. Y. Zhang, "Estimation of scavenging activity of phenolic compounds using the $\mathrm{ABTS}^{++}$assay," Journal of Agricultural and Food Chemistry, vol. 52, pp. 4669-4674, 2004. 
[19] H. Ohkawa, N. Ohishi, and K. Yagi, "Assay for lipid peroxides in animal tissues by thiobarbituric acid reaction," Analytical Biochemistry, vol. 95, no. 2, pp. 351-358, 1979.

[20] M. M. Bradford, "A rapid and sensitive method for the quantitation of microgram quantities of protein utilizing the principle of protein-dye binding," Analytical Biochemistry, vol. 72, no. 1-2, pp. 248-254, 1976.

[21] R. Jover, X. Ponsoda, J. V. Castell, and M. J. Gómez-Lechón, "Evaluation of the cytotoxicity of ten chemicals on human cultured hepatocytes: predictability of human toxicity and comparison with rodent cell culture systems," Toxicology in Vitro, vol. 6, no. 1, pp. 47-52, 1992.

[22] D. M. Maron and B. N. Ames, "Revised methods for the Salmonella mutagenicity test," Mutation Research/Environmental Mutagenesis and Related Subjects, vol. 113, no. 3-4, pp. 173215, 1983.

[23] M. D. Burke, S. Thompson, R. J. Weaver, C. R. Wolf, and R. T. Mayers, "Cytochrome P450 specificities of alkoxyresorufin Odealkylation in human and rat liver," Biochemical Pharmacology, vol. 48, no. 5, pp. 923-936, 1994.

[24] M. Hayashi, R. R. Tice, J. T. MacGregor et al., "In vivo rodent erythrocyte micronucleus assay," Mutation Research/Environmental Mutagenesis and Related Subjects, vol. 312, no. 3, pp. 293304, 1994.

[25] N. Khan and H. Mukhtar, "Dietary agents for prevention and treatment of lung cancer," Cancer Letters, vol. 359, no. 2, pp. 155164, 2015.

[26] D. W. Nebert, T. P. Dalton, A. B. Okey, and F. J. Gonzalez, "Role of aryl hydrocarbon receptor-mediated induction of the CYP1 enzymes in environmental toxicity and cancer," The Journal of Biological Chemistry, vol. 279, no. 23, pp. 23847-23850, 2004.

[27] L. W. Wattenberg, A. B. Hanley, G. Barany, V. L. Sparnins, L. K. Lam, and G. R. Fenwick, "Inhibition of carcinogenesis by some minor dietary constituents," Princess Takamatsu Symposia, vol. 16, pp. 193-203, 1985.

[28] R. Singh, R. J. Sram, B. Binkova et al., “The relationship between biomarkers of oxidative DNA damage, polycyclic aromatic hydrocarbon DNA adducts, antioxidant status and genetic susceptibility following exposure to environmental air pollution in humans," Mutation Research/Fundamental and Molecular Mechanisms of Mutagenesis, vol. 620, no. 1-2, pp. 83-92, 2007.

[29] S. Bhagavathy and P. Sumathi, "Evaluation of antigenotoxic effects of carotenoids from green algae Chlorococcum humicola using human lymphocytes," Asian Pacific Journal of Tropical Biomedicine, vol. 2, no. 2, pp. 109-117, 2012.

[30] Y. Okai, K. Higashi-Okai, S.-I. Nakamura, Y. Yano, and S. Otani, "Suppressive effects of the extracts of Japanese edible seaweeds on mutagen-induced umu $\mathrm{C}$ gene expression in Salmonella typhimurium (TA 1535/pSK 1002) and tumor promotor-dependent ornithine decarboxylase induction in BALB/c 3T3 fibroblast cells," Cancer Letters, vol. 87, no. 1, pp. 25-32, 1994.

[31] L. A. Stoddart, N. J. Smith, and G. Milligan, "Free fatty acid receptors FFA1, -2, and -3: pharmacology and pathophysiological functions," Pharmacological Reviews, vol. 60, no. 4, pp. 405417, 2008.

[32] S. R. Nadathur, J. R. Carney, S. J. Gould, and A. T. Bakalinsky, "Palmitic acid is the major fatty acid responsible for significant anti-N-methyl-N'-nitro-N-nitrosoguanidine (MNNG) activity in yogurt," Mutation Research/Environmental Mutagenesis and Related Subjects, vol. 359, no. 3, pp. 179-189, 1996. 


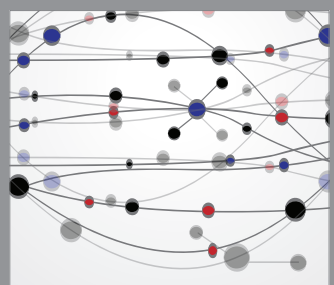

The Scientific World Journal
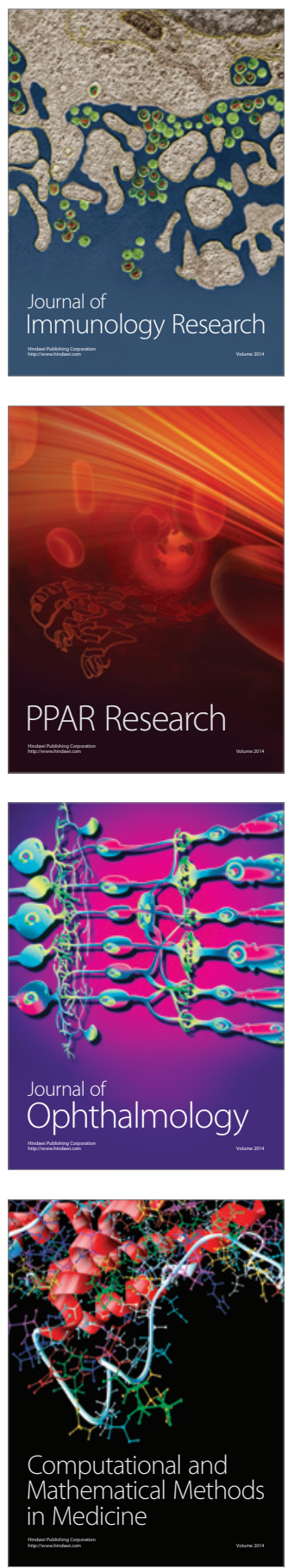

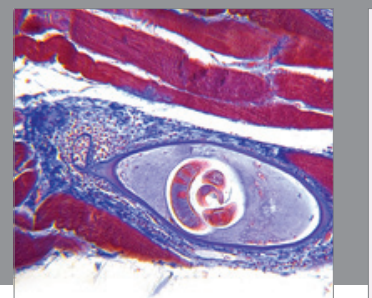

Gastroenterology

Research and Practice
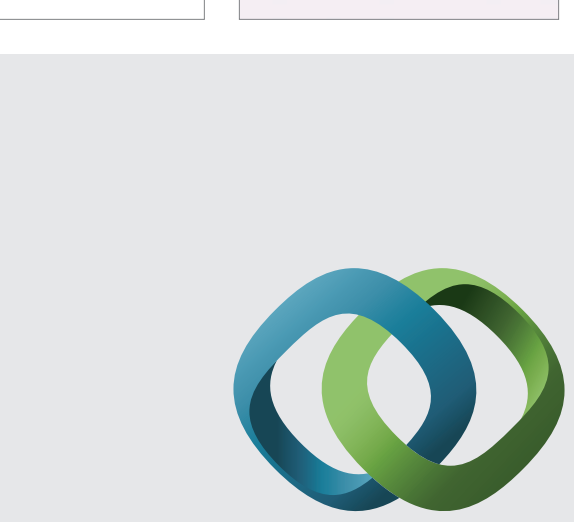

\section{Hindawi}

Submit your manuscripts at

http://www.hindawi.com
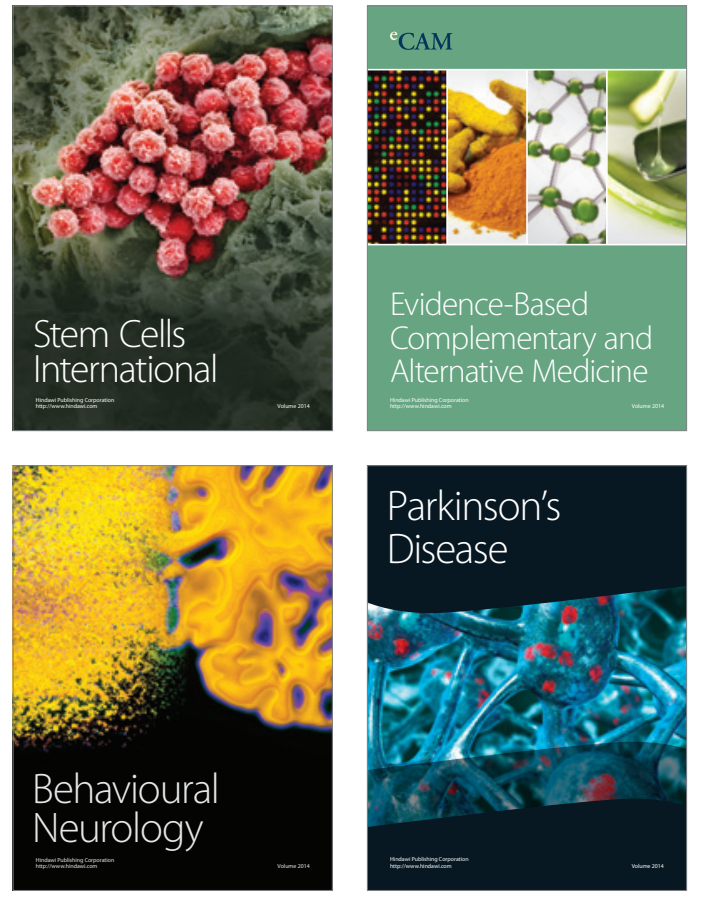
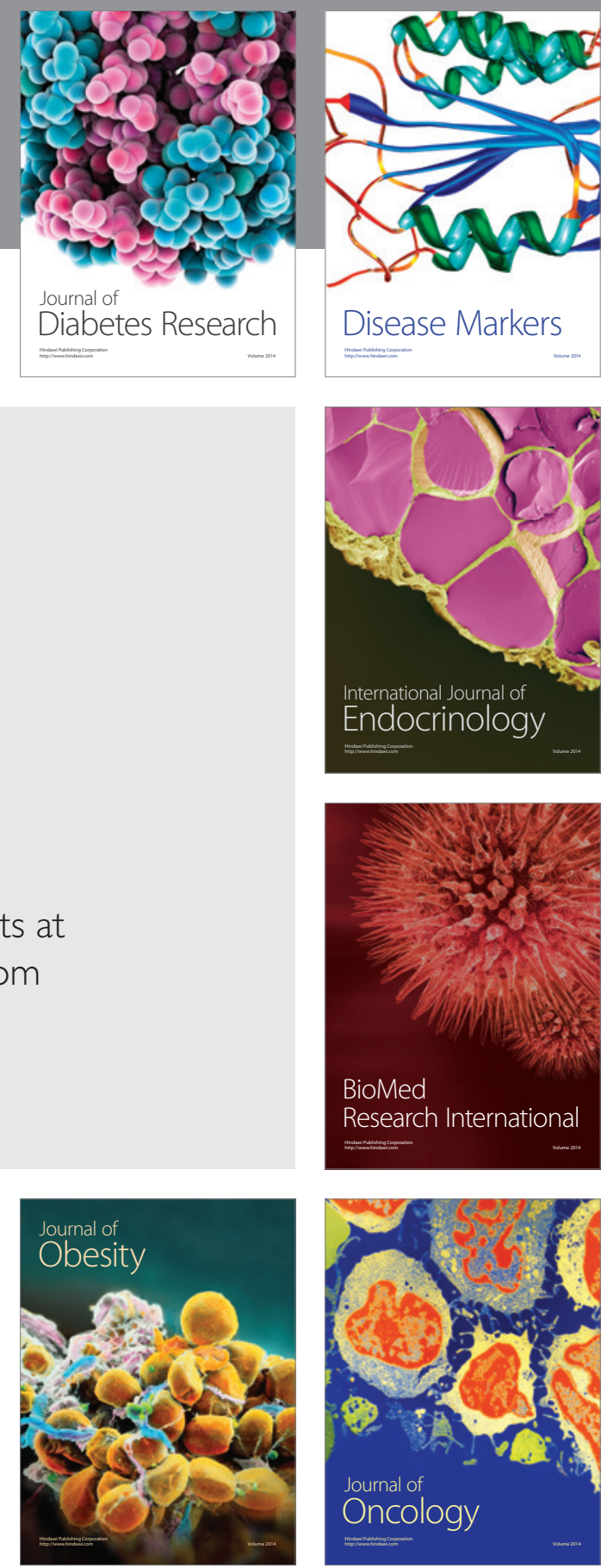

Disease Markers
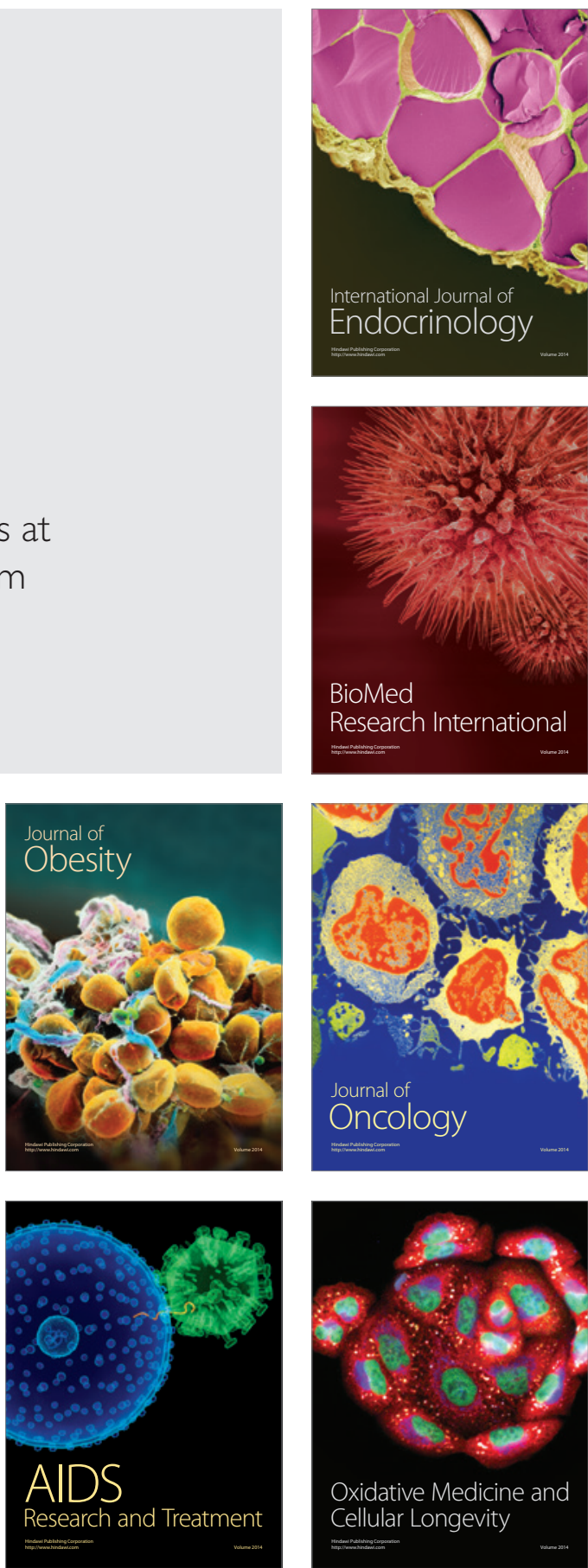